\title{
NOTES
}

\section{ADMIT THE CRIME OR DO THE TIME: PENNSYLVANIA'S JUVENILE TRANSFER CONUNDRUM}

\author{
Lauren M. Kelly ${ }^{*}$
}

\section{INTRODUCTION}

What is punishment? It is the infliction of pain, sorrow, and grief. To take a child from the comfort of his home, the joy of his companions and the freedom of field, river and wood, and confine him to a building with white-washed walls, regimented routine and institutional hours is punishment in the strictest sense of the word. ${ }^{1}$

On the morning of February 20, 2009, twenty-six-year-old Kenzie Houk was shot in the back of the head while she was sleeping in her home in rural western Pennsylvania. ${ }^{2}$ The victim, who was eight-and-a-half-months pregnant, died of the single shotgun wound to the back of her head and neck. ${ }^{3}$ Her viable fetus died due to lack of oxygen. ${ }^{4}$ There was no indication of any provocation on the part of the

\footnotetext{
* J.D. Candidate, 2012, University of Pittsburgh School of Law; B.A., 2009, University of Pittsburgh. Special thanks to my parents, Lawrence and Marisa, and my sisters, Erica, Gianna and Ariana, for their support during the writing of this note.

${ }^{1}$ In re Holmes, 109 A.2d 523, 530 (Pa. 1954) (Musmanno, J., dissenting).

${ }^{2}$ Commonwealth v. Brown, No. 320 of 2009, CR, OTN: K843595-4, 2010 WL 5763593, at *1 (C.P. Lawrence Mar. 29, 2010), vacated, 26 A.3d 485 (Pa. Super. Ct. 2011) [hereinafter Brown I].

${ }^{3} I d$.

${ }^{4} I d$.
} 


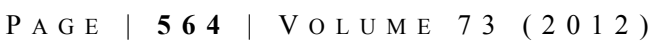

victim. $^{5}$ The Commonwealth established evidence suggesting that the suspect removed the spent shell casing, returned the shotgun to a bedroom in the home, and left, depositing the shell casing along a pathway in the driveway. ${ }^{6}$ A ballistics report later revealed that the shell was fired from the suspect's shotgun, and gunpowder residue was found on the shirt that he was wearing on the day of the shooting. ${ }^{7}$ Following the incident, the defendant was charged with criminal homicide ${ }^{8}$ and homicide of an unborn child. ${ }^{9}$

Jordan Brown was much like any other fifth-grade boy. He attended school, participated in sports, and enjoyed reading and hunting with his father. ${ }^{10}$ However, there is something drastically different between Jordan and other children his age. Unlike those children, Jordan does not reside with his family in western Pennsylvania. Instead, since 2009, he has called the Edmund L. Thomas Adolescent Detention Center his home. ${ }^{11}$ At the age of eleven, Jordan was charged with the above-described murder of his father's fiancée, Kenzie Houk. ${ }^{12}$ In Pennsylvania, the criminal court system has original jurisdiction over murders; therefore, Jordan moved to have his case transferred to juvenile court. ${ }^{13}$ The Lawrence County Court of Common Pleas ruled that Jordan failed to prove that his case (Brown I) should be transferred to juvenile court as required by the Pennsylvania Juvenile Act. ${ }^{14}$ As a result, he would be tried as an adult in criminal proceedings. Had he been convicted, Jordan Brown would have been the youngest person in the United States to be sentenced to life imprisonment without parole, the mandatory sentence for the crimes with which he was charged. ${ }^{15}$ In March 2011,

\footnotetext{
${ }^{5} I d$. at $* 3$.

${ }^{6} I d$. at $* 1$.

${ }^{7}$ Id. at $* 3$.

8 18 PA. CONS. STAT. § 2501 (2006).

${ }^{9}$ Id. § 2603; Brown I, 2010 WL 5763593, at *1.

${ }^{10}$ Jordan's Family, SAVE JORDAN BROwN, http://jordanbrowntrust.org/family.html (last visited Oct. 20, 2012).

11 See Stephanie Chen, Boy, 12, Faces Grown Up Murder Charges, CNN (Feb. 10, 2010), http://articles.cnn.com/2010-02-10/justice/pennsylvania.young.murder.defendant_1_juvenile-homicidejordan-s-attorneys?_s=PM:CRIME.

${ }^{12}$ Brown I, 2010 WL 5763593, at*1.

${ }^{13}$ Id.

${ }^{14}$ Id. at *7.
} 
the Superior Court of Pennsylvania vacated and remanded the case on appeal, finding that Brown's Fifth Amendment right against self-incrimination had been violated due to improper application of the statute by the trial court. ${ }^{16}$ In August 2011, the trial court reversed its earlier decision and transferred Jordan Brown's case to the juvenile division of the court. ${ }^{17}$

The ruling that Jordan Brown would be tried as an adult was controversial on its face, as Jordan was only eleven years old when he allegedly committed the crime. While some criticized the trial court judge for ruling that an eleven-year-old must stand trial as an adult, ${ }^{18}$ those criticisms were specious, as the judge did properly apply the law. There is a more fundamental problem. Many transfer hearings, also known as "decertification hearings," often boil down to whether the juvenile is amenable to treatment in the juvenile facility. ${ }^{19}$ As in Jordan Brown's case, it seemed that in order to show amenability to treatment, the child must have had to take responsibility for the crime. As noted in Brown I, "[T] he first step towards rehabilitation is to take responsibility for the underlying offense." ${ }^{20}$ In cases such as these, it is not the reasoning of the courts that is flawed, but the law itself. Pennsylvania's juvenile transfer statute puts the child in a type of catch-22: admit to the crime and be tried as a juvenile or maintain innocence and be tried in the adult criminal justice system. Therefore, while the Superior Court's ruling in Brown's case was beneficial to him, it will not stop the problem from recurring in other juvenile cases. The Pennsylvania legislature should take steps to reform the statute or insert additional safeguards so that the Fifth Amendment rights of juveniles are not compromised in transfer proceedings.

Part II of this note will discuss the history of the juvenile system and the juvenile transfer mechanism. Part III will examine the current statutory and case

\footnotetext{
${ }^{15}$ Brief for Appellant at 26, Commonwealth v. Brown, 26 A.3d 485 (Pa. Super. Ct. 2011) (No. 1159 WDA 2010), 2010 WL 6546796 at *26.

${ }^{16}$ Commonwealth v. Brown, 26 A.3d 485, 510 (Pa. Super. Ct. 2011).

${ }^{17}$ Commonwealth v. Brown, No. 320 of 2009, CR, OTN: K843595-4, at 1 (C.P. Lawrence Aug. 23, 2011) [hereinafter Brown II].

${ }^{18}$ See, e.g., Andrea Canning \& Maggie Burbank, Jordan Brown Murder Case Takes Emotional Toll, ABC NightLINE (Apr. 28, 2010), http://abcnews.go.com/Nightline/jordan-brown-murder-case-12-yearadult/story?id=10288704\&page=3\#.TwSvZxyofV8 ("I think the judge's decision in this case is both disappointing, and I think, misinformed .... The judge is saying in order to be tried as a juvenile you need to admit that you've done the crime. That doesn't seem quite right to me.").

${ }^{19}$ See 42 PA. CONS. STAT. § 6355(a)(4)(iii)(G) (2006).

${ }^{20}$ Brown I, 2010 WL 5763593, at *6.
} 
U N I V E R S I T Y O F P I T T S B U R G H L A W R E V I E W

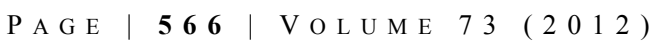

law governing juvenile transfers to and from the criminal system in Pennsylvania. Part IV of this note will demonstrate, through Pennsylvania case law and that of other jurisdictions with similar statutes, that the Pennsylvania Juvenile Act is flawed, as it implicitly requires juveniles to admit guilt without immunizing those incriminating statements from use in decertification proceedings. Finally, Part V will examine the implications of reforming the Juvenile Act. This note will argue that public policy merits these changes, even though it may mean that fewer juveniles are tried in the adult criminal system.

\section{BACKGROUND AND HISTORY}

\section{A. The History of the Juvenile Court}

The juvenile court first emerged in 1899 in Chicago, Illinois. ${ }^{21}$ It differed from the criminal system in various ways, but the most significant difference between the two systems was their respective goals. While the criminal court system focused mainly on traditional retribution with the goal of punishment, the purpose of the juvenile system was to rehabilitate children and to "prevent them from entering a lifetime of crime." 22 The focus was on the juvenile as an individual and, thus, on providing him or her with individualized services and treatment. ${ }^{23}$

At its inception, juvenile jurisdiction was based on the doctrine of parens patriae, which describes the role of the state as "guardian of persons under legal disability," such as juveniles. ${ }^{24}$ Therefore, the juvenile offender was seen as needing the state's care, guidance, and help in rehabilitation. ${ }^{25}$ The ultimate philosophy of the juvenile system was that:

[T]he child who has begun to go wrong, who is incorrigible, who has broken a law or an ordinance, is to be taken in hand by the state, not as an enemy but as a protector, as the ultimate guardian, because either the unwillingness or inability

${ }^{21}$ Lisa A. Cintron, Rehabilitating the Juvenile Court System: Limiting Juvenile Transfers to Adult Criminal Court, 90 Nw. U. L. Rev. 1254, 1257 (1996); Catherine R. Guttman, Listen to the Children: The Decision to Transfer Juveniles to Adult Court, 30 HARV. C.R.-C.L. L. REV. 507, 511 (1995).

${ }^{22}$ Francis Barry McCarthy, The Serious Offender and Juvenile Court Reform: The Case for Prosecutorial Waiver of Juvenile Court Jurisdiction, 38 ST. LoUIS U. L.J. 629, 641 (1994).

${ }^{23}$ Cintron, supra note 21, at 1257.

${ }^{24}$ Guttman, supra note 21, at 511.

${ }^{25}$ Cintron, supra note 21 , at 1258. 
of the natural parents to guide it toward good citizenship has compelled the intervention of the public authorities. ${ }^{26}$

The rationale behind the rehabilitative approach stemmed from the beliefs of nineteenth-century common law and society that children were not fully responsible for their actions. ${ }^{27}$ Therefore, they "should be shielded from the punishment that would be exacted from a responsible actor," in other words, an adult. $^{28}$ Thus, the juvenile court was made as a separate forum to address the special needs of children with a heavy emphasis on social and psychological inquiries. ${ }^{29}$ Moreover, judges had broad discretion to make decisions that were considered to be in the best interest of the child. ${ }^{30}$

Another difference in the goals of the criminal and juvenile systems was marked by the juvenile system's attempts to eliminate the stigma of criminalization. ${ }^{31}$ For example, instead of declaring the child "convicted" or "guilty," the juvenile would be adjudicated "delinquent" or "in need of the court's help"; the juvenile offender was not labeled a criminal, but was labeled "delinquent"; the proceedings were private, unlike the public proceedings of a criminal trial; and finally, the proceedings were considered civil and not criminal in nature. ${ }^{32}$ Each of these elements of the juvenile system was consistent with the goal of rehabilitation and made the process less adversarial. The nature of the juvenile system also allowed the child to re-enter society afresh. ${ }^{33}$ Simply stated, the juvenile system was designed to provide whatever was necessary to give children another chance. $^{34}$

The original scope of the juvenile system was somewhat limited and not intended to deal with major offenders, as evidenced by the Illinois Juvenile Court

${ }^{26} I d$.

${ }^{27}$ Id. at $1258-59$.

${ }^{28}$ McCarthy, supra note 22, at 641.

${ }^{29}$ Guttman, supra note 21 , at 512 .

${ }^{30}$ Barry C. Feld, Violent Youth and Public Policy: A Case Study of Juvenile Justice Law Reform, 79 MinN. L. ReV. 965, 971 (1995).

${ }^{31}$ Guttman, supra note 21, at 511.

${ }^{32}$ Cintron, supra note 21, at 1259; Guttman, supra note 21, at 511.

${ }^{33}$ Guttman, supra note 21, at 511.

${ }^{34}$ Id. at 512. 


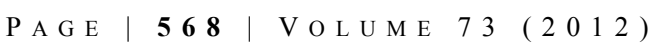

Act, ${ }^{35}$ one of the first American juvenile acts. ${ }^{36}$ Instead, the intent was to deal with minor offenders who had the potential for future criminal behavior. ${ }^{37}$ From there, however, the scope of juvenile acts across the country began to expand. By 1933, the Pennsylvania juvenile court had original jurisdiction over all crimes committed within the Commonwealth by children under the age of sixteen, except for murder. $^{38}$

The juvenile system continued to evolve procedurally as well. In the case In re Gault, ${ }^{39}$ the United States Supreme Court held that juveniles were to be afforded certain procedural due process rights, such as the right to notice of charges, to counsel, to confrontation and cross-examination of witnesses, and to the privilege against self-incrimination. ${ }^{40}$ The Court in Gault noted that the denial of procedural rights frequently resulted in arbitrariness rather than the juvenile system's proclaimed goal of "careful, compassionate, individualized treatment."41

Furthermore, three years later in In re Winship, ${ }^{42}$ the Supreme Court held that a finding of "delinquency" must be made beyond a reasonable doubt, instead of the lower, civil standard of a preponderance of the evidence. ${ }^{43}$ The addition of these procedural rights altered the original form of juvenile proceedings, making them more formal and adversarial. ${ }^{44}$ Along with the procedural changes came the modern notion that the goal of the juvenile court should be to hold juveniles accountable for their actions; thus, the rehabilitative approach has been somewhat abandoned in favor of an expansion of the scope and authority of the juvenile justice system. $^{45}$

\footnotetext{
${ }^{35}$ Act of April 21, 1899, 1899 Ill. Laws 131-32.

${ }^{36}$ McCarthy, supra note 22, at 643.

${ }^{37} \mathrm{Id}$. at $642-44$.

${ }^{38} I d$. at 645 .

${ }^{39} 387$ U.S. 1 (1967).

${ }^{40}$ See id.

${ }^{41}$ Feld, supra note 30, at 971-72 (quoting Gault, 387 U.S. at 18).

${ }^{42} 397$ U.S. 358, 368 (1970).

${ }^{43}$ See id.

${ }^{44}$ Cintron, supra note 21, at 1260.

${ }^{45}$ McCarthy, supra note 22, at 641-42.
} 


\section{B. The Juvenile Transfer Mechanism}

Initially, transfers from juvenile court to criminal court were the exception; however, they have become increasingly common today. ${ }^{46}$ The rationale behind the originally limited use of the transfer mechanism was that "children should be protected and rehabilitated rather than subjected to the harshness of the criminal system because children, all children, are worth redeeming. ${ }^{, 47}$ In those extenuating circumstances, however, when the transfer mechanism was necessary, courts employed it where the juvenile offender was not found to be amenable to treatment in the juvenile system. ${ }^{48}$ In Kent v. United States, ${ }^{49}$ the United States Supreme Court set out factors for courts to consider in assessing whether the juvenile's case should be transferred,${ }^{50}$ noting that the transfer decision is "critically important," as

${ }^{46}$ Cintron, supra note 21, at 1261; Guttman, supra note 21, at 515.

${ }^{47}$ Cintron, supra note 21, at 1261 (internal citations omitted).

${ }^{48} I d$. at 1257.

49383 U.S. 541 (1966).

${ }^{50}$ The factors listed by the Kent Court were:

1. The seriousness of the alleged offense to the community and whether the protection of the community requires waiver.

2. Whether the alleged offense was committed in an aggressive, violent, premeditated or willful manner.

3. Whether the alleged offense was against persons or against property, greater weight being given to offenses against persons especially if personal injury resulted.

4. The prosecutive merit of the complaint, i.e., whether there is evidence upon which a Grand Jury may be expected to return an indictment (to be determined by consultation with the United States Attorney).

5. The desirability of trial and disposition of the entire offense in one court when the juvenile's associates in the alleged offense are adults who will be charged with a crime in the U.S. District Court for the District of Columbia. 6. The sophistication and maturity of the juvenile as determined by consideration of his home, environmental situation, emotional attitude and pattern of living.

7. The record and previous history of the juvenile, including previous contacts with the Youth Aid Division, other law enforcement agencies, juvenile courts and other jurisdictions, prior periods of probation to this Court, or prior commitments to juvenile institutions.

8. The prospects for adequate protection of the public and the likelihood of reasonable rehabilitation of the juvenile (if he is found to have committed the alleged offense) by the use of procedures, services and facilities currently available to the Juvenile Court.

Kent v. United States, 383 U.S. 541, 566-67 (1966). 
it determines the juvenile's relationship with the criminal justice system and greatly affects his future. ${ }^{51}$ Indeed, the decision of whether to transfer the case affects more than just the forum. It determines whether the juvenile will be afforded the "special rights and immunities" of juvenile court and whether he will come away with an adult criminal conviction and all of the accompanying consequences. ${ }^{52}$

\section{Current Pennsylvania Law Governing Juvenile TRANSFERS}

The Pennsylvania Juvenile $\mathrm{Act}^{53}$ governs transfers from criminal court to juvenile court in Pennsylvania. ${ }^{54}$ The self-proclaimed purpose of the Act is to "provide for children committing delinquent acts programs of supervision, care and rehabilitation which provide balanced attention to the protection of the community, the imposition of accountability for offenses committed and the development of competencies to enable children to become responsible and productive members of the community." 55 Pennsylvania employs a form of legislative waiver that automatically excludes juveniles charged with certain crimes from the juvenile court and directly transfers them to the adult court. ${ }^{56}$ The criminal court, for instance, has original jurisdiction over acts of murder. ${ }^{57}$ Additionally, there are several other offenses enumerated in $\S 6302$ that do not constitute "delinquent acts" and, thus, give the criminal court original jurisdiction. ${ }^{58}$ Section 6322 goes on to state that in determining whether to transfer a case charging murder, or any of the offenses excluded from the definition of "delinquent act," the burden of proof is upon the juvenile to establish by a preponderance of the evidence that the transfer

${ }^{51}$ Kent, 383 U.S. at 560; see also Guttman, supra note 21, at 513-14.

${ }^{52}$ Cintron, supra note 21, at 1261 (quoting Kent, 383 U.S. at 556).

${ }^{53} 42$ PA. CONS. STAT. $\S$ 6301-6375 (2006).

${ }^{54} I d . \S 6355$.

${ }^{55} I d . \S 6301(\mathrm{~b})(2)$.

${ }^{56}$ Cintron, supra note 21 , at $1267-68$.

${ }^{57} 42$ PA. CONS. STAT. $§ 6322$ (2006).

${ }^{58}$ Those offenses include conduct where the child was fifteen years or older at the time and a deadly weapon was used during a rape, involuntary deviant sexual intercourse, aggravated assault, robbery, robbery of a motor vehicle, aggravated indecent assault, kidnapping, voluntary manslaughter, or attempt, conspiracy or solicitation to commit murder or any of these crimes. Additionally, a child will be subject to criminal proceedings if he was fifteen years or older and had been previously adjudicated delinquent of any of the above-mentioned conduct. Summary offenses do not constitute "delinquent acts." 42 PA. CONS. STAT. § 6302 (2006). 
will serve the public interest. ${ }^{59}$ In determining whether the child has satisfied his burden, the court is to consider the factors set forth in $\S 6355$ (a)(4)(iii) ${ }^{60}$

Section 6355(a)(4) states that the court may transfer the case from juvenile to criminal court if there is a prima facie case that the child committed the delinquent act alleged, it would be a felony if committed by an adult, there are reasonable grounds to believe that the public interest is served by the transfer of the case for criminal prosecution, and there are reasonable grounds to believe that the child is not mentally retarded or mentally ill. ${ }^{61}$ In determining whether the public interest will be served, the court shall consider several factors, ${ }^{62}$ the most contentious of which is typically "whether the child is amenable to treatment, supervision or rehabilitation as a juvenile." vested in the criminal court, "the public policies affording a juvenile different

${ }^{59} 42$ PA. CONS. STAT. § 6322(a).

${ }^{60}$ See infra note 62.

${ }^{61} 42$ PA. CONS. STAT. § 6355(a)(4) (2006).

${ }^{62}$ The full list of factors is:

(A) the impact of the offense on the victim or victims;

(B) the impact of the offense on the community;

(C) the threat to the safety of the public or any individual posed by the child;

(D) the nature and circumstances of the offense allegedly committed by the child;

(E) the degree of the child's culpability;

(F) the adequacy and duration of dispositional alternatives available under this chapter and in the adult criminal justice system; and

(G) whether the child is amenable to treatment, supervision or rehabilitation as a juvenile by considering the following factors:

(I) age;

(II) mental capacity;

(III) maturity;

(IV) the degree of criminal sophistication exhibited by the child;

(V) previous records, if any;

(VI) the nature and extent of any prior delinquent history, including the success or failure of any previous attempts by the juvenile court to rehabilitate the child;

(VII) whether the child can be rehabilitated prior to the expiration of the juvenile court jurisdiction;

(VIII) probation or institutional reports, if any;

(IX) any other relevant factors.

Id. § 6355(a)(4)(iii).

${ }^{63} I d . \S 6355(\mathrm{a})(4)(\mathrm{iii})(\mathrm{G})$. 
U N I V E R S I T Y O F P I T T S B U R G H L A W R E V I E W

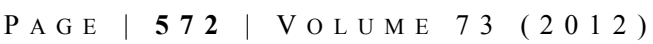

treatment than adults are no longer applicable." ${ }^{64}$ Additionally, the criminal court, in deciding whether to decertify a case to juvenile court, must consider all of the statutory factors set forth in $\S 6355$ (a)(4)(iii); however, the Juvenile Act is "silent as to the weight [to] be assessed to each [factor] by the court.",65

\section{Flaws in the Pennsylvania Juvenile Transfer STATUTE}

\section{A. The Act Implicitly Requires an Admission of Guilt for Decertification to Juvenile Court}

The landmark juvenile transfer case in Pennsylvania is Commonwealth $v$. Pyle, ${ }^{66}$ in which the Supreme Court of Pennsylvania held that "where murder is charged, treatment as a 'youthful offender' still does not arise as a matter of right." ${ }^{\text {67 }}$ While Pyle was decided before the current form of the Juvenile Act was enacted, it is still cited by courts reviewing transfer decisions. ${ }^{68}$ Since the Act's 1995 amendment, ${ }^{69}$ Pennsylvania courts have uniformly applied the seven-factor test set forth in $\S 6355(\mathrm{a})(4)(i i i)$. The standard of review for appealing a decertification decision is a particularly heavy burden for the juvenile to overcome. As the Supreme Court of Pennsylvania noted in In re E.F.," the "ultimate decision of whether to certify a minor to stand trial as an adult is within the sole discretion of a juvenile court. An appellate court may not disturb a certification ruling unless the juvenile court committed an abuse of discretion.,"71

In Jordan Brown's case, the trial court evaluated whether he could be rehabilitated prior to the expiration of the juvenile court's jurisdiction. ${ }^{72}$ In support of its contention that Brown was not amenable to rehabilitation, the

\footnotetext{
${ }^{64}$ Commonwealth v. Carter, 855 A.2d 885, 891 (Pa. Super. Ct. 2004).

${ }^{65}$ Commonwealth v. Sanders, 814 A.2d 1248, 1251 (Pa. Super. Ct. 2003).

${ }^{66} 342$ A.2d 101 (Pa. 1975).

${ }^{67} I d$. at 104.

${ }^{68}$ See, e.g., Commonwealth v. Aziz, 724 A.2d 371, 375 (Pa. Super. Ct. 1999); Commonwealth v. Cotto, 708 A.2d 806, 813 (Pa. Super. Ct. 1998); Commonwealth v. Behr, 43 Pa. D. \& C.3d 27, 32 (C.P. Erie 1987).

${ }^{69}$ See Cotto, 708 A.2d at 811.

${ }^{70} 995$ A.2d 326 (Pa. 2010).

${ }^{71}$ Id. at 329 (quoting Commonwealth v. Jackson, 722 A.2d 1030, 1032, 1034 (Pa. 1999)).

${ }^{72}$ See Brown I, 2010 WL 5763593, at *1.
} 
Commonwealth presented the testimony of Dr. John O'Brien, a physicianpsychiatrist. ${ }^{73}$ Dr. O'Brien found that the defendant's "amenability to rehabilitation is limited because of [the] tendency to minimize, to deny and to shift blame and that the first step towards rehabilitation cannot be taken unless [the defendant] would come forward and take responsibility for his actions, which is not likely to occur." 74

The trial court ultimately held that Brown was not likely to be rehabilitated. ${ }^{75}$ While the court noted that it was not concluding as a matter of law that the child must confess, ${ }^{76}$ it stated:

[W]e find agreement on the conclusion that rehabilitation requires taking responsibility for the underlying offense; and, persuasive reasoning from Dr. O'Brien that the taking of such responsibility is unlikely to occur, thus making the prospects of rehabilitation within the confines of the juvenile court jurisdiction likely to be unsuccessful. ${ }^{77}$

Therefore, after considering the factors of $\S 6355(\mathrm{a})(4)(\mathrm{iii})$ and finding that, under $\S 6355(a)(4)($ iii) $(G)$, Brown would not likely be rehabilitated in the juvenile system, the court held that he failed to meet his burden of proving that a transfer to juvenile court would serve the public interest. ${ }^{78}$

As illustrated by Jordan Brown's case, the Pennsylvania transfer statute essentially requires the juvenile to admit to committing the crime in order to be decertified to juvenile court. The juvenile must take responsibility for his actions and show remorse, but the situation becomes complicated where the juvenile did not commit the crime. This is where the Hobson's choice ${ }^{79}$ arises for the juvenile. The child must show that he is amenable to treatment in the juvenile facility in order to be tried in juvenile court. In Jordan Brown's case, he insisted that he did

${ }^{73} I d$. at $* 5$.

${ }^{74} I d$.

${ }^{75} I d$. at $* 6$.

${ }^{76} \mathrm{Id}$.

${ }^{77} \mathrm{Id}$.

${ }^{78} I d$. at $* 7$.

${ }^{79}$ A "Hobson's choice" is "an apparently free choice that actually offers no alternative." Hobson's Choice, Dictionary.com, http://dictionary.reference.com/browse/hobson's+choice (last visited Oct. 20, 2012). 
not commit the crime, while at the same time asserting that he was amenable to treatment in the juvenile facility in order to have his case decertified. ${ }^{80}$ However, if he did not commit the crime, why would he need treatment? The Pennsylvania Juvenile Act puts juveniles like Jordan Brown in this difficult and illogical position.

Prior juvenile transfer challenges in Pennsylvania did not come to this. Often, courts rested their decisions to uphold the denial of transfer on other grounds, rather than on whether the juvenile pled guilty or maintained his innocence. One oft-stated basis that courts use to find that the juvenile was properly placed in the adult system is his age. Often times, the older the juvenile is, the less likely it is that the court will find that he can be rehabilitated before the expiration of the juvenile court's jurisdiction, which occurs at age twenty-one. ${ }^{81}$ By making age the main focus of the decision, the court does not have to make the fact that the juvenile maintained his innocence a central issue. In other cases, such considerations as insufficient time for rehabilitation in the juvenile system for older juveniles and defendants' prior criminal or juvenile record have influenced courts to uphold denials of decertification. ${ }^{82}$ The prior offenses show that the juvenile system has previously failed in attempting to rehabilitate the child.

${ }^{80}$ See generally Brown I.

${ }^{81}$ See Commonwealth v. Moyer, 444 A.2d 101 (Pa. 1982) (holding that the twenty-year-old defendant was not likely to be rehabilitated in one year); Commonwealth v. Sourbeer, 422 A.2d 116 (Pa. 1980) (relying on psychiatrist's testimony that the fifteen-year-old defendant would not likely be rehabilitated until ages thirty-five to forty); Commonwealth v. Pyle, 342 A.2d 101 (Pa. 1975) (holding that the seventeen-year-old defendant could not be rehabilitated by age twenty-one); Commonwealth v. Zoller, 498 A.2d 436 (Pa. Super. Ct. 1985) (concluding that five years in the juvenile system was not sufficient to rehabilitate the defendants); Commonwealth v. Caraballo, 12 Pa. D. \& C.5th 17 (C.P. Berks 2010) (holding that the defendant, aged twenty years, five months, could not be rehabilitated before the expiration of juvenile court jurisdiction).

${ }^{82}$ See Commonwealth v. Pennington, 751 A.2d 212 (Pa. Super. Ct. 2000) (finding that a nineteen-yearold defendant with prior offenses could not be rehabilitated before juvenile jurisdiction expired); Commonwealth v. Aziz, 724 A.2d 371 (Pa. Super. Ct. 1999) (concluding that the case of a seventeenyear-old defendant with prior offenses, exhibiting a history of violent, criminal behavior should not be decertified to juvenile court); Commonwealth v. Morningwake, 595 A.2d 158 (Pa. Super. Ct. 1991) (holding that the nearly sixteen-year-old defendant charged with first degree murder could not be rehabilitated by the time juvenile jurisdiction expired, and that prior crimes were suggestive of unsuccessful rehabilitation in the juvenile center); Commonwealth v. Leatherbury, 568 A.2d 1313 (Pa. Super. Ct. 1990) (noting that only three years in the juvenile facility would not be enough to rehabilitate and that previous attempts to rehabilitate had proven unsuccessful). 
Additionally, similar to Jordan Brown's case, courts have also based denials of decertification on the fact that the defendant showed no remorse. ${ }^{83}$ For example, in Commonwealth v. Kocher, ${ }^{84}$ in which a nine-year-old boy was charged with murdering his neighbor, the child was found to have demonstrated a lack of remorse by dozing off to sleep during pretrial motions. ${ }^{85}$ The lower court denied Kocher's motion for transfer to the juvenile court. ${ }^{86}$ Alternatively, if the defendant takes responsibility for his actions, admits to the crime, and shows remorse, Pennsylvania courts have tended to find that he is amenable to treatment in the juvenile facility. ${ }^{87}$ In Commonwealth $v$. Behr, after the victim had taunted the fifteen-year-old defendant, the defendant went into his house, came out with a shotgun and shot the victim three times, killing him. ${ }^{88}$ Among the reasons the Court of Common Pleas of Erie County cited for decertifying the case to juvenile court were that the defendant was not mature or strong enough to survive in the adult system, ${ }^{89}$ he never had problems in school nor did he have prior offenses, ${ }^{90}$ he showed great remorse for the victim, ${ }^{91}$ and he understood the enormity and horror of the shooting. ${ }^{92}$ Moreover, because the defendant could be rehabilitated before the juvenile court's jurisdiction expired, the court decertified his case to the juvenile court. $^{93}$

${ }^{83}$ See Commonwealth v. Smith, 950 A.2d 327, 329 (Pa. Super. Ct. 2008) (defendant apologized "halfheartedly" to his victim, refusing to take responsibility for his actions); Commonwealth v. Zoller, 498 A.2d 436, 440 (Pa. Super. Ct. 1985) (holding that defendants showed no remorse and "hardness of heart" after luring a mentally retarded man to a pre-dug grave, beating him over the head with the shovel, robbing him, and dragging him into the grave, where he was found dead two months later).

${ }^{84}$ Commonwealth v. Kocher, 602 A.2d 1308 (Pa. 1992).

${ }^{85}$ Robert Schwartz, Kids Should Never Be Tried As Adults, CNN (Feb. 18, 2010), http://www.cnn.com/ 2010/OPINION/02/18/schwartz.kids.trials/index.html.

${ }^{86}$ Kocher, 602 A.2d at 1313 . The lower court was reversed by the Supreme Court of Pennsylvania for erroneously finding that a juvenile murder defendant is required to prove that a mental disease or defect caused the killing in order to demonstrate amenability to treatment in the juvenile system. $I d$. at 1315 .

${ }^{87}$ See, e.g., In re E.F., 995 A.2d 326 (Pa. 2010) (holding that a twenty-one-year-old defendant who was charged with sexual assault of a child when he was twelve years old and who admitted to the crime had rehabilitated himself between the ages of twelve and twenty-one).

${ }^{88}$ Commonwealth v. Behr, 43 Pa. D. \& C.3d 27 (C.P. Erie 1987).

${ }^{89} I d$. at 38 .

${ }^{90} I d$. at $39-40$.

${ }^{91} I d$. at 42 .

${ }^{92} I d$. at 50 .

${ }^{93}$ Id. at $55-56$. 
U N I V E R S I T Y O F P I T T S B U R G H L A W R E V I E W

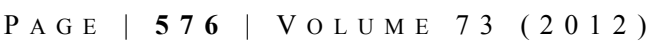

In contrast, Jordan Brown had no prior offenses ${ }^{94}$ and he was twelve years old at the time of the decertification hearing, leaving nine years for potential rehabilitation in the juvenile center. ${ }^{95}$ While he may not have shown remorse for the victim, this was due to the fact that he maintained his innocence. Therefore, the trial court in Brown I seemed to treat as dispositive the fact that Jordan would not take responsibility for his actions.

The Supreme Court of California, in a case involving a similar statute and similar predicament, found that its juvenile transfer statute violated juveniles' Fifth Amendment right against self-incrimination due to the untenable choice they were forced to make. The court likened the juvenile in a decertification hearing to a probationer, noting that a "policy underlying the privilege against selfincrimination which is undermined by forcing a probationer to choose between the privilege and his opportunity to be heard at his revocation hearing is our 'unwillingness to subject those suspected of crime to the cruel trilemma of selfaccusation, perjury or contempt." 96 The court conceded that although a minor is not faced with contempt if he remains silent at his decertification hearing, he may find himself in a similar situation. ${ }^{97}$

The consequences of this trilemma could be devastating for the juvenile:

He might ... seriously incriminate himself if he exercises his right to be heard, particularly where his testimony would consist of a truthful explanation of mitigating circumstances surrounding the charged [offense]. If he remains silent he not only loses his opportunity to present a conceivably convincing case [for treatment under the juvenile court laws] but also incurs the risk that notwithstanding the ideals of the Fifth Amendment, his silence will be taken as an indication that there are no valid reasons why [he should not be tried as an adult]. To avoid the adverse effects of the foregoing alternatives, the [minor] may be tempted to testify falsely in a manner which will not damage his defense at a subsequent criminal trial. To force an individual to choose one of three such

\footnotetext{
${ }^{94}$ Brown I, 2010 WL 5763593, at *4.

${ }^{95} \mathrm{Id}$.

${ }^{96}$ Ramona R. v. Superior Court, 693 P.2d 789, 794 (Cal. 1985) (citing Murphy v. Waterfront Comm'n, 378 U.S. 52, 55 (1964)).

${ }^{97}$ Id.
} 
unpalatable alternatives runs counter to our historic aversion to cruelty reflected in the privilege against self-incrimination. ${ }^{98}$

Therefore, while the Pennsylvania statute does not explicitly require that a juvenile admit to the crime to be decertified to juvenile court, it does so implicitly. Juveniles in Pennsylvania who wish to maintain their innocence are thus subjected to the "cruel trilemma" of which the California Supreme Court spoke. ${ }^{99}$ For this reason, the determination of amenability in the juvenile court system should not be based on whether the juvenile has taken responsibility for his actions or admitted to the crime. Instead, and more appropriately, Pennsylvania courts should focus on factors such as the defendant's age and prior history within the juvenile system in determining amenability.

\section{B. There Is No Immunity Provision in the Pennsylvania Juvenile Act to Protect the Juvenile's Right Against Self- Incrimination During Transfer Proceedings}

Another constitutional safeguard is providing juveniles with use immunity for statements made during transfer proceedings. Courts across the United States have found that requiring a juvenile to make the unfair choice that Jordan Brown had to make, without the assurance that the statement would be inadmissible for use in transfer proceedings or in a subsequent trial, violates the child's Fifth Amendment right against self-incrimination. ${ }^{100}$ While Pennsylvania does have a provision which gives immunity to a juvenile's statements from being used in a subsequent trial, it does not protect the child from use of the statements in the transfer proceedings. ${ }^{101}$

${ }^{98} I d$. (internal citations omitted).

${ }^{99} I d$.

${ }^{100}$ See In re William M., 196 P.3d 456, 457 (Nev. 2008) (“[R]equiring a juvenile to admit to the charged criminal conduct in order to overcome the presumption of adult certification ... violates the juvenile's Fifth Amendment right against self-incrimination.”); Christopher P. v. State, 816 P.2d 485 (N.M. 1991) (holding that a juvenile's Fifth Amendment rights were violated when the court compelled him to discuss the alleged offenses with a psychologist without the advice of counsel); Ramona R., 693 P.2d 789 (holding that use immunity applies to statements a juvenile makes at a fitness hearing because, without it, the juvenile's right against self-incrimination is violated). $C f$. State ex rel. A.L., 638 A.2d 814, 822 (N.J. Super. Ct. App. Div. 1994) ("There are no Fifth Amendment concerns where the threat of self-incrimination is removed by a grant of immunity.").

10142 PA. CONS. STAT. $§ 6338(c)(1)$ (2006) provides:

No statements, admissions or confessions made by or incriminating information obtained from a child in the course of a screening or assessment that is undertaken in conjunction with any proceedings under this chapter, 
U N I V E R S I T Y O F P I T T S B U R G H L A W R E V I E W

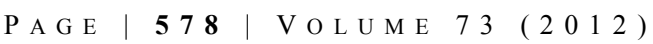

\section{Commonwealth v. Cotto}

In 1998, the Superior Court of Pennsylvania heard the case of Commonwealth v. Cotto. $^{102}$ In Cotto, a juvenile, charged as an adult, challenged the constitutionality of the Juvenile Act. More specifically, the juvenile alleged that the statute unconstitutionally places the burden of proof on the juvenile to transfer his case from criminal to juvenile court. ${ }^{103}$ In rejecting this claim, the court referred to the New Jersey case State in Interest of A.L. ${ }^{104}$ In A.L., the New Jersey Superior Court held that the state's transfer statute did not violate a juvenile's right against self-incrimination because, even if an admission of guilt by the juvenile were required, that testimony is fully immunized and therefore he is "not penalized in any way by testifying at the transfer hearing." 105 The Cotto court noted that:

The Pennsylvania Juvenile Act does not provide immunity to a juvenile testifying at his transfer hearing. Although the absence of such a provision does not affect our decision as to constitutionality, we believe that inclusion of an immunity provision would be prudent and merits legislative consideration. ${ }^{106}$

Therefore, while the lack of immunity of the juvenile's statements at this stage in the proceedings did not affect the court's decision regarding constitutionality, specifically the juvenile's claim that the burden was impermissibly placed on him, the court made clear that it would be wise for the legislature to immunize such statements. It is unclear how the court would have ruled if the juvenile had explicitly challenged the Fifth Amendment selfincrimination issue.

including but not limited to, that which is court ordered, shall be admitted into evidence against the child on the issue of whether the child committed a delinquent act under this chapter or on the issue of guilt in any criminal proceeding.

Transfer proceedings do not determine whether the child committed a delinquent act, nor do they go toward the issue of guilt. Therefore, such proceedings are not included under this provision.

${ }^{102}$ Commonwealth v. Cotto, 708 A.2d 806 (Pa. Super. Ct. 1998).

${ }^{103}$ Id. at 813 .

${ }^{104}$ A.L., 638 A.2d 814.

${ }^{105}$ Cotto, 708 A.2d at 815 n.3 (citing A.L., 638 A.2d at 822).

${ }^{106} I d$. (emphasis added). 


\section{In the Matter of William $M$.}

Other jurisdictions have tackled the same issue that Jordan Brown faced more directly. Most recently, the Supreme Court of Nevada, in In the Matter of William $M$., ruled that requiring a juvenile to admit to a crime in order to overcome the presumption of adult certification violates the Fifth Amendment right against selfincrimination. ${ }^{107}$ In that case, the seventeen-year-old defendant maintained his innocence, and the juvenile court found that he did not rebut the presumption of certification in adult court. ${ }^{108}$ As in Cotto, the court noted that the result of a transfer hearing is not an adjudication of guilt. ${ }^{109}$ However, as both the Supreme Court of Nevada and the California Supreme Court have recognized, "the certification of a juvenile offender to an adult court has been accurately characterized as 'the worst punishment the juvenile system is empowered to inflict." "110 While the statute in Nevada required a somewhat more explicit admission of guilt, ${ }^{111}$ the fact remains that the Pennsylvania statute has the same effect. By requiring the juvenile to take responsibility for his actions and show remorse in order to prove that he is amenable to treatment in the juvenile facility, the juvenile is implicitly required to admit guilt.

\section{Christopher P. v. State}

The Supreme Court of New Mexico in Christopher P. v. State held that a juvenile's Fifth Amendment right against self-incrimination was violated when the court ordered the child to discuss the charges against him during a psychological evaluation to be used to determine amenability to treatment in transfer proceedings. ${ }^{112}$ While the state of New Mexico contended that the transfer proceedings were nonadversarial and intended only to determine forum, not guilt, the court mimicked the sentiments of the Supreme Court of Nevada in William

\footnotetext{
${ }^{107}$ In re William M., 196 P.3d 456, 457 (Nev. 2008).

${ }^{108}$ Id. at 458.

${ }^{109}$ Id. at 463. See also Cotto, 708 A.2d at 814.

${ }^{110}$ William M., 196 P.3d at 463 (citing Ramona R. v. Superior Court, 693 P.2d 789, 795 (Cal. 1985)).

111 "The plain language of NRS 62B.390(3)(b) requires that a juvenile present clear and convincing evidence that his or her actions were substantially influenced by either substance abuse or emotional or behavioral problems. Accordingly, a juvenile must present evidence that his substance abuse or emotional or behavioral problems substantially influenced his commission of the charged criminal actions. In other words, to rebut the presumptive certification, the juvenile must incriminate himself." William M., 196 P.3d at 464.

${ }^{112}$ Christopher P. v. State, 816 P.2d 485, 486 (N.M. 1991).
} 
U N I V E R S I T Y O F P I T T S B U R G H L A W R E V I E W

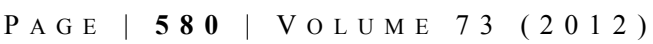

$M .^{113}$ The court noted the impact of the transfer proceedings, stating that the transfer decision "does more than determine a judicial forum for an accused youth. It invokes a jurisprudential philosophy that governs the nature of the proceedings as well as the purpose and severity of the sanctions." "114 The court concluded that the protections of the Fifth Amendment extend to official questions in any kind of proceeding, the answers to which may incriminate the juvenile in future criminal proceedings. ${ }^{115}$

\section{Ramona R. v. Superior Court}

Finally, the Supreme Court of California addressed a similar issue in Ramona $R$. v. Superior Court, when it found that in order to comply with the constitutional protections of the Fifth Amendment, use immunity must apply to the state's juvenile statute. ${ }^{116}$ In that case, the seventeen-year-old juvenile defendant was charged with brutally murdering her guardian. ${ }^{117}$ The child refused to be interviewed by a probation officer and declined to testify at the transfer hearing. ${ }^{118}$ Furthermore, counsel for the defendant did not introduce into evidence a psychiatric evaluation of the child, as there was no immunity provision in place for potentially incriminating statements. ${ }^{119}$ In addition to recognizing that the lack of immunity subjected the child to the "cruel trilemma" of choosing between selfincrimination, perjury, and contempt, the court noted that it also "impermissibly lighten[s]" the prosecution's burden at the guilt phase. ${ }^{120}$ Finally, the court noted that although the result of the decertification hearing is not an adjudication of guilt, certification to adult court can have crippling consequences for the juvenile and his future. $^{121}$

${ }^{113} I d$.

${ }^{114}$ Id. at 487 (quoting Martin L. Forst \& Martha-Elin Bloomquist, Cracking Down on Juveniles: The Changing Ideology of Youth Corrections, 5 Notre DAME J.L. ETHICS \& PUB. POL'Y 323, 339 (1991)) (emphasis added).

${ }^{115}$ Id. at 487 (citing Lefkowitz v. Turley, 414 U.S. 70, 77 (1973)).

${ }^{116}$ See 693 P.2d 789 (Cal. 1985).

${ }^{117}$ Id. at 791.

${ }^{118} I d$.

${ }^{119} I d$.

${ }^{120} \mathrm{Id}$. at 794 .

${ }^{121} I d$. at 795 (quoting Note, Separating the Criminal from the Delinquent: Due Process in Certification Procedure, 40 S. CAL. L. REv. 158, 162 (1967)). 
No Pennsylvania statute prohibits the use of incriminating statements made by a juvenile during decertification proceedings. ${ }^{122}$ While the Pennsylvania statute does not explicitly require or compel juveniles to admit to the crime, it implicitly compels the unfair choice of either admitting guilt to show amenability and stay in juvenile court or maintaining innocence and going to the adult criminal system. Therefore, the juvenile's Fifth Amendment right against self-incrimination is called into question. Because the Pennsylvania statute has no immunity provision to protect the child, his constitutional rights are violated. Pennsylvania should enact such a provision in order to bring the Juvenile Act in conformity with the protections and policies of the right against self-incrimination.

\section{Implications of Reforming the Pennsylvania JUVENILE ACT}

Removing the implicit requirement that juveniles must admit to the crime to be decertified to juvenile court may result in the courts finding more juveniles amenable to treatment in the juvenile facility. While there are certainly arguments in support of certifying juveniles to the adult criminal system, the stronger arguments, especially in terms of policy and current societal norms, counsel in favor of keeping juveniles in the juvenile system.

\section{A. Children Are Psychologically Different Than Adults}

Many of the rationales for keeping juveniles in the juvenile system stem from the psychological differences between children and adults. Robert Schwartz, cofounder of the Juvenile Law Center, has commented on the implications of Jordan Brown's case and about juvenile transfers in general. Schwartz cites to a study by the MacArthur Foundation Network on Adolescent Development and Juvenile Justice, ${ }^{123}$ which found that "teenagers are less blameworthy than adults, and that their capacities change significantly over the course of adolescence." ${ }^{, 124}$ In other words, the study suggested that juveniles simply cannot process information and plan a crime like an adult. ${ }^{125}$ Schwartz goes on to state that during adolescence, children "struggle with their immaturity, undeveloped decision-making abilities, impulsiveness, lack of future orientation and susceptibility to negative peer

\footnotetext{
${ }^{122} C f .42$ PA. CONS. STAT. $\S 6338(c)(1)(2006)$.

${ }^{123}$ Schwartz, supra note 85.

${ }^{124} I d$.

${ }^{125} \mathrm{Id}$.
} 
U N I V E R S I T Y O F P I T T S B U R G H L A W R E V I E W

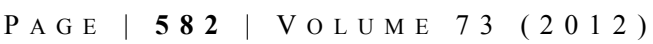

pressure." ${ }^{26} \mathrm{He}$ also points to scientific evidence drawn from brain imaging technology. This imaging shows that the teenage brain undergoes dramatic changes in several areas during adolescence, affecting adolescents' ability to reason, weigh the consequences of decisions, and delay gratification long enough to make careful short- and long term choices. ${ }^{127}$

United States Supreme Court jurisprudence mimics these sentiments regarding the psychological make-up of children. In Roper $v$. Simmons the Supreme Court considered the constitutionality of capital punishment for juveniles. ${ }^{128}$ The Court ultimately held that it was a violation of the Eighth and Fourteenth Amendments to impose the death penalty on offenders who were under the age of eighteen when they committed their crimes. ${ }^{129}$ In coming to its decision, the Court noted the differences in culpability between adults and children. Quoting the plurality opinion in Thompson v. Oklahoma, ${ }^{130}$ the Court noted that " $[\mathrm{t}] \mathrm{he}$ reasons why juveniles are not trusted with the privileges and responsibilities of an adult also explain why their irresponsible conduct is not as morally reprehensible."131 Additionally, the Court agreed with the Thompson plurality's determination that the death penalty did not have an impact as a deterrent on juveniles, as there is "a low likelihood that offenders under 16 engaged in "the kind of cost-benefit analysis that attaches any weight to the possibility of execution." ",132

The Court also heavily relied upon the psychological differences between children and adults, noting three main differences. The first is a lack of maturity and underdeveloped sense of responsibility in juveniles as compared to adults; ${ }^{133}$ the Court stated that this often leads juveniles to make "impetuous and illconsidered actions and decisions." 134 Additionally, because of this, youths tend to act more recklessly than do adults. ${ }^{135}$ As evidence of the state-recognized

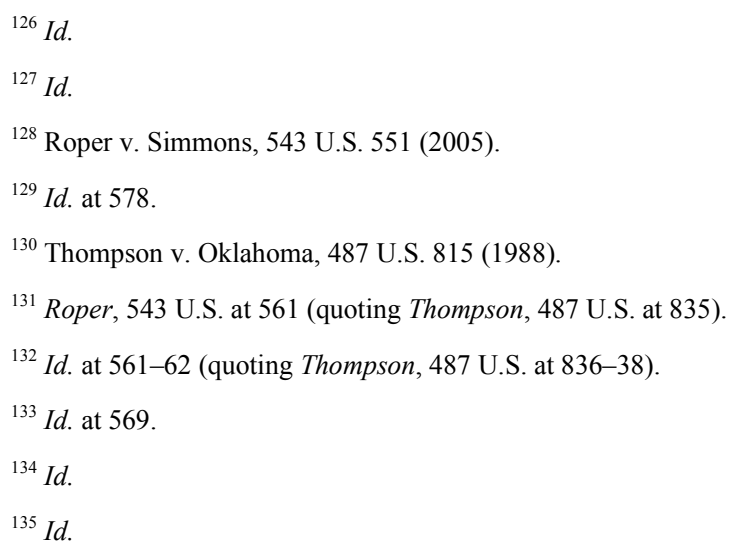


differences between the maturity of juveniles and adults, the Court noted that children cannot vote, serve on juries, or marry without parental consent. ${ }^{136}$

The second psychological divergence between juveniles and adults that the Court discussed is that youths are more susceptible to negative influences and peer pressure. ${ }^{137}$ This is due to the fact that youths do not have as much control over their own environment and surroundings. ${ }^{138}$ Lastly, the Court noted that the third difference between the psychological functioning of juveniles and adults is that the character of a juvenile is "not as well formed as that of an adult." 139 For these reasons, the Court found that children should not be subject to the death penalty. It noted that it would be wrong from a moral standpoint "to equate the failings of a minor with those of an adult, for a greater possibility exists that a minor's character deficiencies will be reformed." 140

Five years later, in Graham v. Florida, the Court considered the constitutionality of imposing a life sentence without the possibility of parole on a non-homicide juvenile offender. ${ }^{141}$ Relying on Roper, the Court reiterated that a juvenile's behavior is "not as morally reprehensible as that of an adult." 142 The Court also pointed to several of the same arguments made in Roper, such as psychological evidence and the ineffectiveness of harsh punishment as a deterrent mechanism, as somewhat mitigating a juvenile's behavior. ${ }^{143}$ Finally, in terms of rehabilitation, the Court found that a life imprisonment sentence without the possibility of parole would not achieve the goal of deterrence. It noted that "by denying the defendant the right to reenter the community, the State makes an irrevocable judgment on the person's value and place in society. This judgment is not appropriate in light of a juvenile nonhomicide offender's capacity for change and limited moral culpability.",144

\footnotetext{
${ }^{136} I d$.

${ }^{137} I d$.

${ }^{138} I d$.

${ }^{139} I d$. at 570 .

${ }^{140} I d$.

${ }^{141}$ Graham v. Florida, 130 S. Ct. 2011 (2010).

${ }^{142} I d$. at 2026.

${ }^{143} I d$. at 2026-28.

${ }^{144} I d$. at 2030.
} 
U N I V E R S I T Y O F P I T T S B U R G H L A W R E V I E W

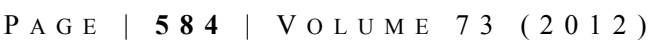

Roper and Graham show the Court's reluctance to treat juveniles and adults exactly the same way. Whether it be rooted in public policy or moral and societal standards, the cases show the Court struggling with, and ultimately finding against, subjecting juvenile offenders to certain aspects of the adult criminal justice system. The same reasoning applied in Roper and Graham can also be applied to modern juvenile transfer cases, such as that of Jordan Brown.

\section{B. Children Are Not Competent Defendants}

Furthermore, researchers at the MacArthur Network found an additional, but somewhat different, psychological reason why youths should not be tried in adult criminal court. That reason is that children are not competent enough to be defendants and can be likened to mentally ill persons not competent to stand trial. They lack adjudicative competence - that is, "the ability of a defendant to stand trial having 'sufficient present ability to consult with his lawyer with a reasonable degree of rational understanding, and whether he has a rational as well as factual understanding of the proceedings against him." "145 The researchers argue that children lack the capacity and ability to consult with their attorneys and shape trial strategy. ${ }^{146}$ The Court in Graham considered this as well, finding that juveniles have "[d]ifficulty in weighing long-term consequences; a corresponding impulsiveness; and reluctance to trust defense counsel.",147

\section{The Criminal Justice System May Do More Harm Than Good to Juveniles}

Finally, there is the fear that "young offenders given adult time will prove to be greater menaces to society when released after having learned the criminal ropes from older, tougher inmates." "Studies have shown that juveniles transferred to the adult criminal system had higher recidivism rates and in a shorter period of time than non-transferred juveniles. ${ }^{149}$ This has caused one observer to call the placement of juveniles into the adult system mere "cosmetic crime control."150

\footnotetext{
${ }^{145}$ Lisette Blumhardt, In the Best Interests of the Child: Juvenile Justice or Adult Retribution?, $23 \mathrm{U}$. HAW. L. REv. 341, 350 (2000) (quoting Dusky v. United States, 362 U.S. 402, 402 (1960)).

${ }^{146}$ Schwartz, supra note 85.

${ }^{147}$ Graham, 130 S. Ct. at 2032.

${ }^{148}$ Blumhardt, supra note 145 , at 355.

${ }^{149}$ Deanie C. Allen, Note, Trying Children as Adults, 6 T.G. Jones. L. Rev. 27,52 (2002). See also Neelum Arya, Using Graham v. Florida to Challenge Juvenile Transfer Laws, 71 LA. L. REV. 99, 141 (2010).

${ }^{150}$ Cintron, supra note 21, at 1282.
} 
Additionally, juveniles incarcerated in adult prisons are more likely to be physically and sexually abused by inmates than those in juvenile facilities. ${ }^{151}$ More specifically, approximately forty-six percent of juveniles in adult prisons are violently attacked; they are sexually assaulted at a rate five times higher than in juvenile facilities; they are physically abused by adult prison employees at twice the rate; and they are eight times more likely to commit suicide than minors in juvenile facilities. ${ }^{152}$ According to a study by Jeffrey Fagan, director of the Center for Violence Research and Prevention at Columbia University, juveniles who are sentenced to prison terms in the adult criminal system are "prisonized." 153 Fagan notes that "developmentally, their identities are very firmly and concretely molded as criminal offenders. And what they do not learn because they are locked up are the skills needed to become a family member, husband, neighbor or worker."154

As for Jordan Brown's case, Robert Schwartz argues that the reasons to keep Brown in the juvenile system are really common sense. ${ }^{155}$ He states that if Jordan is adjudicated delinquent in juvenile proceedings, he will remain in the juvenile system until his twenty-first birthday. Schwartz states that this is "certainly long enough to serve the needs of public protection, and enough time to rehabilitate [an eleven-year-old] child." $156 \mathrm{He}$ also notes that in cases such as these, the juvenile system is more effective at protecting the public against violent juvenile offenders than the adult criminal system. ${ }^{157}$

\section{Public Policy}

Public policy counsels in favor of decertifying minors to juvenile court. As stated by the Supreme Court in Graham, "every child under the age of eighteen ... is entitled to the chance to 'atone for his crimes and learn from his mistakes' so that he may 'demonstrate that the bad acts he committed as a teenager are not representative of his true character." "158 The Court in Graham also noted that long

\footnotetext{
${ }^{151} I d$.

${ }^{152}$ Suka Rassouli, Comment, Cruel and Unusual Punishment: Juvenile Offenders Sentenced to Adult Prisons, 8 WhitTier J. ChiLD \& FAM. Advoc. 261, 262 (2009).

${ }^{153}$ Blumhardt, supra note 145 , at 355.

${ }^{154} I d$.

${ }^{155}$ Schwartz, supra note 85.

${ }^{156} I d$. Jordan Brown was eleven years old at the time of the incident in 2009.

${ }^{157} I d$.

${ }^{158}$ Arya, supra note 149, at 102 (quoting Graham v. Florida, 130 S. Ct. 2011, 2033 (2010)).
} 
U N I V E R S I T Y O F P I T T S B U R G H L A W R E V I E W

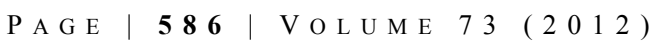

sentences, such as life imprisonment without the possibility of parole, are quite severe when applied to youth because "[a] 16-year-old and a 75-year-old each sentenced to life without parole receive the same punishment in name only." "In Pennsylvania, a concurrence in Kocher, authored by Justice Flaherty, expressed that Pennsylvania's public policy would not allow for the criminal prosecution of a nine-year-old child. ${ }^{160}$ Justice Flaherty found the attempt at prosecuting a child as young as Cameron Kocher shocking to the conscience. ${ }^{161}$ Furthermore, scholars have criticized transfer laws on the basis that "there is little reason to believe that the juvenile system can accurately predict which juveniles are, indeed, beyond rehabilitative efforts and should therefore be remanded to the adult system in the name of public safety." 162 In light of our society's evolving standards of decency, ${ }^{163}$ condemning extremely young children such as Jordan Brown to long, harsh sentences in the adult criminal system is contrary to American public policy and should be avoided whenever possible.

\section{Conclusion}

While reasonable minds may disagree as to whether Jordan Brown murdered Kenzie Houk, the Fifth Amendment guarantees his right to maintain his innocence. Pennsylvania's Juvenile Act implicitly requires the juvenile to admit guilt in order to show amenability in the juvenile facility. Moreover, the statute contains no safeguards, such as immunity, to protect the child in the decertification hearing from incriminating statements he may make. The psychological differences between children and adults, along with issues concerning adjudicative competency, the effectiveness of the adult system on juveniles, and general public policy, counsel in favor of keeping juveniles in the juvenile system. The legislature in Pennsylvania should look to the evolving standards of decency in the United States in reforming the Pennsylvania Juvenile Act and protecting the Fifth Amendment rights of juveniles. As the original philosophy of the juvenile court system proclaimed, the state should not be an enemy of the child, but a protector and ultimate guardian. ${ }^{164}$

\footnotetext{
${ }^{159}$ Graham, 130 S. Ct. at 2028.

${ }^{160}$ Commonwealth v. Kocher, 602 A.2d 1308, 1315-16 (Pa. 1992) (Flaherty, J., concurring).

${ }^{161} I d$. at 1316 .

${ }^{162}$ Arya, supra note 149, at 131 (quoting M.A. Bortner, Traditional Rhetoric, Organizational Realities: Remand of Juveniles to Adult Court, 32 CRIME \& DELINQ. 53, 59 (1986)) (internal quotations omitted).

${ }^{163}$ See generally Graham v. Florida, 130 S. Ct. 2011 (2010).

${ }^{164}$ Cintron, supra note 21, at 1258.
} 